ISSN 1392-3196 / e-ISSN 2335-8947

Zemdirbyste-Agriculture, vol. 107, No. 2 (2020), p. 171-178

DOI $10.13080 / \mathrm{z}-\mathrm{a} .2020 .107 .022$

\title{
Factors affecting organogenesis of Stevia rebaudiana and in vitro accumulation of steviol glycosides
}

\author{
Aušra BLINSTRUBIENĖ, Natalija BURBULIS, Neringa JUŠKEVIČIŪTĖ, Rasa ŽŪKIENĖ \\ Vytautas Magnus University \\ K. Donelaičio 58, Kaunas, Lithuania \\ E-mail: ausra.blinstrubiene@vdu.lt
}

\begin{abstract}
The aim of this research was to investigate the effect of explant type and cytokinin type and concentration on stevia direct organogenesis in vitro, and to determine the effect of cytokinin type on stevioside and rebaudioside A content in regenerated shoots.

Stem and leaf segments of stevia (Stevia rebaudiana Bertoni), taken from 6-week-old in vitro grown plants, were inoculated on Murashige and Skoog (MS) medium supplemented with different $(1.0-6.0 \mu \mathrm{M})$ concentrations of 6-benzylaminopurine (BAP), thidiazuron (TDZ) and kinetin (KIN) for shoot regeneration. The content of steviol glycosides (stevioside and rebaudioside A) in $S$. rebaudiana donor plants and regenerated shoots was evaluated using high-performance liquid chromatography (HPLC). Results revealed a significant effect $(p<0.01)$ of explant type, cytokinin type and cytokinin concentration on shoot regeneration frequency. The mean value of regeneration frequency from stem segments was significantly higher in comparison with leaf segments. Thidiazuron significantly promoted the mean regeneration frequency in comparison to 6-benzylaminopurine and kinetin. The highest mean shoot formation frequency was obtained on the medium supplemented with $3.0 \mu \mathrm{M}$ of TZD. Incorporation of 4.0 $\mu \mathrm{M}$ BAP and 4.0 $\mu \mathrm{M}$ TZD into culture media resulted in significant increase in rebaudioside A and stevioside ratio, while a decrease in rebaudioside $A$ and stevioside ratio was recorded when the medium was supplemented with $4.0 \mu \mathrm{M}$ KIN. Rebaudioside A and stevioside ratio in the medium supplemented with $4.0 \mu \mathrm{M}$ TZD was significantly higher in comparison with $4.0 \mu \mathrm{M}$ BAP and $4.0 \mu \mathrm{M}$ KIN.
\end{abstract}

Key words: cytokinin, explant, rebaudioside A, shoot regeneration, stevia, stevioside.

\section{Introduction}

Stevia (Stevia rebaudiana Bertoni) is a perennial herb $(65-80 \mathrm{~cm}$ tall) belonging to Asteraceae family (Lemus-Mondaca et al., 2012). The origin of $S$. rebaudiana is northern regions of South America, and it is vastly distributed in the highlands of Amambay, located at Iguac district, a border between Brazil and Paraguay (Madan et al., 2010). The medicinal importance of $S$. rebaudiana is ascribed to the presence of diterpene glycosides including stevioside (3-10\%), rebaudioside A (13\%) and rebaudioside B, C and D in its leaves (Chaturvedula, Prakash, 2011). These glycosides are 100-300 times sweeter than those of sucrose (Lopes et al., 2015). Diterpene glycosides produced by $S$. rebaudiana are an approved dietary supplement by the U.S. Food \& Drug Administration (2018) and comparatively low-calorie sweeteners due to which they are highly recommended for diabetic and obesity patients (Chan et al., 2000; Lee et al., 2001; Luwańska et al., 2015). According to reports, steviol glycosides have no effect on blood sugar level and exhibit strong antifungal and antibacterial properties (Thiyagarajan,
Venkatachalam, 2012). The quantity of $S$. rebaudiana steviol glycosides varies among the plant organs and shows a gradual decrease in the following order: leaves, flowers, stems and seeds. The roots of $S$. rebaudiana are the sole organs that do not produce any steviosides or steviol glycosides (Yadav et al., 2011). Up to now, 32 steviol glycosides have been identified in the leaves of S. rebaudiana (Bergs et al., 2012). As an alternative natural sweetener and effective medicine for diabetes, $S$. rebaudiana is economical and easily accessible due to its wide distribution (Anton et al., 2010).

In recent years, plant scientists are focusing on the development of optimum protocols for plant species having enormous medicinal and industrial importance in order to obtain homogenous and highly vigorous plants in a short period. This can ultimately reduce the labour cost and time, which are higher in conventional propagation and breeding techniques. The protocol optimization for micropropagation involves various factors such as the type and concentrations of hormones in the media, type of media, etc. (George, Debergh, 2008; Jain et al., 2009).

Please use the following format when citing the article:

Blinstrubienė A., Burbulis N., Juškevičiūtė N., Žūkienė R. 2020. Factors affecting organogenesis of Stevia rebaudiana and in vitro accumulation of steviol glycosides. Zemdirbyste-Agriculture, 107 (2): 171-178. DOI 10.13080/z-a.2020.107.022 
Normally, S. rebaudiana can be propagated through seed and stem cuttings. However, the propagation by seed involves many problems like low fertility, selfincompatibility, small seed size, poor germination and heterogeneity, which consequently results in a change in the level and composition of stevioside (natural sweetener) (Sivaram, Mukundan, 2003; Yadav et al., 2011). In addition, propagation through stem has also various drawbacks like low frequency of shoot emergence and physical damage to the donor plant (Yadav et al., 2011). Considering these problems micropropagation or in vitro culture seems to be the ideal tool for the propagation of S. rebaudiana.

All the biochemical processes in plants are mainly carried out by various plant growth regulators including auxins, gibberellins, cytokinins, abscisic acid, ethylene and brassinosteroids. These plant growth regulators profoundly influence the vital functions such as cell division and its differentiation into different tissues and organs. The type and concentration of these plant growth regulators have a notable effect on the plant's physiology. In in vitro propagation of plants, medium plays a significant part in defining the morphogenetic pathway (Gupta et al., 2015).

A number of studies have been conducted for setting up an optimized micropropagation protocol involving various plant growth regulators for S. rebaudiana. Razak et al. (2014) used 6-benzylaminopurine (BAP) and kinetin (KIN) for the shoot development and indole-3-acetic acid (IAA) for root development in in vitro micropropagation of Malaysian $S$. rebaudiana (explants were the nodal segments). Maximum shoot formation (7.82 \pm 0.7 shoots per explants) was observed using $0.5 \mathrm{mg} \mathrm{L}^{-1} \mathrm{BAP}$ and $0.25 \mathrm{mg} \mathrm{L}^{-1} \mathrm{KIN}$. In another study, Singh and Dwivedi (2013) tested BAP, KIN, IAA and indole-3-butyric acid (IBA) both alone and in combination to check their effect on shoot and root formation of stevia in in vitro culture. Results revealed that lower concentrations of the used plant growth regulators were more effective in all the treatments.

In another report, the authors used chlorocholine chloride (CCC) for its possible positive effect on biomass, survivability of the plantlets and stevioside production. Results revealed that microshoots grown in MS medium supplemented with different combinations and concentrations of CCC and IBA were found to be most effective in terms of growth pattern, hardening ability of the plantlets and stevioside content, compared to the control where no CCC was used (Dey et al., 2013). Incorporation of the different concentrations of $\mathrm{CuSO}_{4} \cdot 5 \mathrm{H}_{2} \mathrm{O}$ into $\mathrm{MS}$ medium considerably improved direct shoot bud initiation and propagation from cultured leaf and nodal explants (Jain et al., 2009). The levels of explants and plant growth regulators have a significant impact on accelerated micropropagation system of $S$. rebaudiana and other plants (Moharami et al., 2014; Gupta et al., 2015).

The aim of this research was to investigate the effect of explant type and cytokinin type and concentration on stevia (Stevia rebaudiana Bertoni) direct organogenesis in vitro and to determine the effect of cytokinin type on stevioside and rebaudioside A content in regenerated shoots.

\section{Materials and methods}

Plant material. This study was carried out during 2016-2017 at Institute of Biology and Plant Biotechnology of Aleksandras Stulginskis University (since 2019 - Vytautas Magnus University) and Department of Biochemistry of Vytautas Magnus University. In order to sterilize the seeds of stevia (Stevia rebaudiana Bertoni), they were soaked in 70\% $\mathrm{C}_{2} \mathrm{H}_{5} \mathrm{OH}$ (ethanol) for $30 \mathrm{~s}$ and $0.1 \% \mathrm{NaClO}$ (sodium hypochlorite) for $20 \mathrm{~s}$, respectively, followed by an extensive wash with sterile water for a couple of times. The sterilized seeds were grown in vitro on a basal MS (Murashige, Skoog, 1962) medium supplemented with $10.0 \mathrm{~g} \mathrm{~L}^{-1}$ sucrose and $8.0 \mathrm{~g} \mathrm{~L}^{-1}$ agar (Carl Roth $\mathrm{GmbH}$, Germany) without supplementing with any growth regulators. Culture media $(20 \mathrm{~mL})$ were dispensed into Petri dishes, and then the seeds were placed on the media. The seeds were incubated at $27 \pm 2^{\circ} \mathrm{C}$ temperature, under illumination of $50 \mu \mathrm{mol} \mathrm{m} \mathrm{m}^{-2} \mathrm{~s}^{-1}$ and photoperiod of $16 / 8 \mathrm{~h}$ (day/night). The explants were transferred on the regeneration medium under aseptic conditions.

In vitro organogenesis and preparation of S. rebaudiana material. In the current study, two different explants, i.e. stem internode segments and leaves, taken from 6-week-old in vitro grown plants, were selected for in vitro propagation of $S$. rebaudiana. In the current study, we investigated the effect of different concentrations of cytokinin on stimulating shoot formation frequency and shoot number per explant. For this purpose, the explants were cultured on MS medium supplemented with different $(1.0-6.0 \mu \mathrm{M})$ concentrations of 6-benzylaminopurine (BAP), thidiazuron (TDZ) and kinetin (KIN), $30.0 \mathrm{~g} \mathrm{~L}^{-1}$ sucrose and $8.0 \mathrm{~g} \mathrm{~L}^{-1}$ agar. The explants were cultivated at $27 \pm 2{ }^{\circ} \mathrm{C}$ temperature, under illumination of $50 \mu \mathrm{mol} \mathrm{m}{ }^{-2}$ $\mathrm{s}^{-1}$ and photoperiod of $16 / 8 \mathrm{~h}$ (day/night) for one month.

Extraction of steviol glycosides. Donor plants as well as shoots, regenerated on the media without growth regulators and supplemented with $4 \mu \mathrm{M}$ BAP, $4 \mu \mathrm{M}$ TDZ or $4 \mu \mathrm{M} \mathrm{KIN}$, were dried at $30^{\circ} \mathrm{C}$ for 24 hours. Dried $S$. rebaudiana material was powdered using a batch mill with a disposable grinding chamber Tube-Mill control (IKA, Germany), $0.2 \mathrm{~g}$ of powder was mixed with $10 \mathrm{~mL}$ of deionized water and the mixture was sonicated for 60 $\min$ at $25^{\circ} \mathrm{C}$. Then the mixture was centrifuged at $16000 \times$ $\mathrm{g}$ for $10 \mathrm{~min}$ at room temperature, the supernatant was collected and kept at $-20^{\circ} \mathrm{C}$ until analysis by HPLC. The extraction was carried out in triplicate.

High-performance liquid chromatography (HPLC) analysis of steviol glycosides. Steviol glycosides (stevioside and rebaudioside A) were separated and quantified using HPLC by a modified method of Bergs et al. (2012). Agilent 1200 series HPLC system (Agilent Technologies Inc., USA) with a diode array detector was used. The samples were filtered through a syringe filter with PVDF (polyvinylidene difluoride) membrane (pore diameter $0.22 \mu \mathrm{m}$ ) and separated on a reversed phase column with Purospher STAR RP-18e (Merck, Germany) $5 \mu \mathrm{m}$ Hibar $2 \times 250 \mathrm{~mm}$ with a precolumn. Injection volume of $10 \mu \mathrm{L}$ was used. The column temperature was maintained at $70^{\circ} \mathrm{C}$. Isocratic elution with a mobile phase consisting of $70 \%$ deionized water acidified with $1 \mathrm{~N} \mathrm{HCl}$ to $\mathrm{pH} 2.75$ and $30 \% \mathrm{C}_{2} \mathrm{H}_{3} \mathrm{~N}$ (acetonitrile) was 
used for separation with additional washing step with $50 \% \mathrm{C}_{2} \mathrm{H}_{3} \mathrm{~N}$ at the flow rate of $0.25 \mathrm{~mL} \mathrm{~min}^{-1}$. Stevioside and rebaudioside A were detected at the wavelength of $210 \mathrm{~nm}$. Identification of stevioside and rebaudioside A in the samples was done by means of retention time, UV spectra and mixed with a standard. The calibration was done by plotting the peak area responses against the concentration values in the concentration range from 1 to $1000 \mu \mathrm{g} \mathrm{mL}^{-1}$ with linear dependence for both the analytes. Each analysis was repeated three times and the mean value was used. Working under an isocratic mode less than 10 min was required to separate the components of interest, without affecting resolution (Fig. 1).

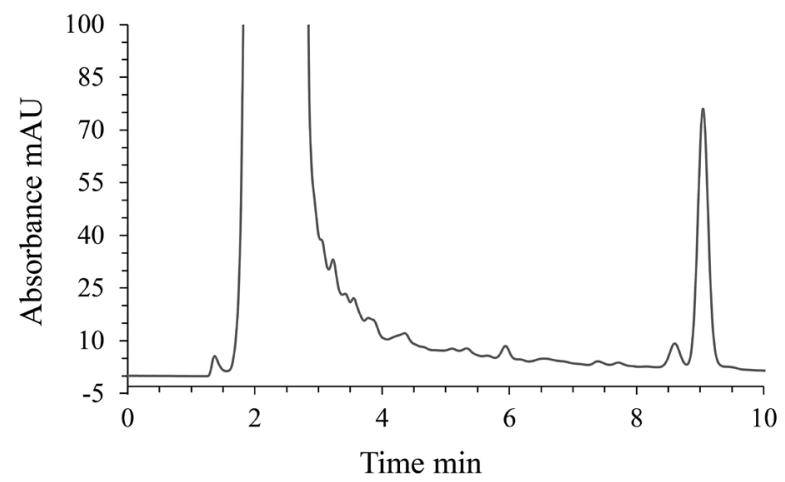

Figure 1. High-performance liquid chromatography (HPLC) chromatogram from Stevia rebaudiana

Statistical analysis. All the experiments were conducted using a completely randomized design with 3 replicates per treatment and 20 explants per each replicate. The percentage of shoot formation and the number of shoots were calculated using the following formulas:

$$
\begin{aligned}
& \text { Shoot formation }(\%)= \\
& \frac{\text { number of explants with adventitious shoots }}{\text { total number of explants }} \times 100, \\
& \text { and } \\
& \begin{array}{l}
\text { Number of shoots }= \\
\text { number of adventitious shoots } \\
\text { number of explants forming adventitious shoots }
\end{array}
\end{aligned}
$$

The statistical analysis of the experimental data was performed by the analysis of variance (ANOVA) using the software package Selekcija (Raudonius, 2017).
The mean value of shoot formation frequency, the number of shoots per explant, amount of steviol glycosides and standard error (SE) were calculated based on the number of independent replications. All percentage values were transformed using arcsine square root $(\sqrt{\mathrm{P}})$ (Compton, 1994) to normalize distribution prior to variance analysis. The effect of factors (explant type, cytokinin type and concentration) and their interaction on regeneration were studied by a three-way analysis of variance. Tukey test was used for multiple comparisons.

\section{Results and discussion}

Organogenesis of Stevia rebaudiana. Regeneration potential of stem segments of $S$. rebaudiana was explored on MS medium without and with various concentarations of the tested cytokinin type (Fig. 2). Results of in vitro organogenesis revealed the shoot formation frequency of $7.78 \%$ (on average) on the MS media without supplementing with any cytokinin. A significant improvement was observed in the overall organogenesis of $S$. rebaudiana after the incorporation of cytokinin into culture medium compared to the control medium (without any plant growth regulators). Considering the results, it was clearly demonstrated that there was a significant effect of type and concentration of cytokinin.

Increasing concentration of cytokinins in the media resulted in the increase of shoot formation frequency. Shoot formation frequency under the influence of KIN was significantly lower compared with BAP and TDZ at all the tested concentrations. Increasing the concentration of BAP from 1.0 to $5.0 \mu \mathrm{M}$ caused a significant increase in the shoot formation frequency; however, a further increase in concentration significantly reduced morphogenic response. On the media with BAP, the shoot formation frequency varied from $25.00 \%$ to $63.89 \%$ with an average of $46.66 \%$, and with KIN from $10.56 \%$ to $23.89 \%$ with an average of $18.61 \%$. The highest shoot formation frequency $(76.67 \%)$ was obtained on the medium supplemented with $3.0 \mu \mathrm{M}$ TDZ. When explants were placed on the medium without growth regulators, shoot number per explant averaged 4.33 (Fig. 3). The highest number of shoots per explant from stem segments was obtained on the medium supplemented with $3.0 \mu \mathrm{M}$ TDZ.

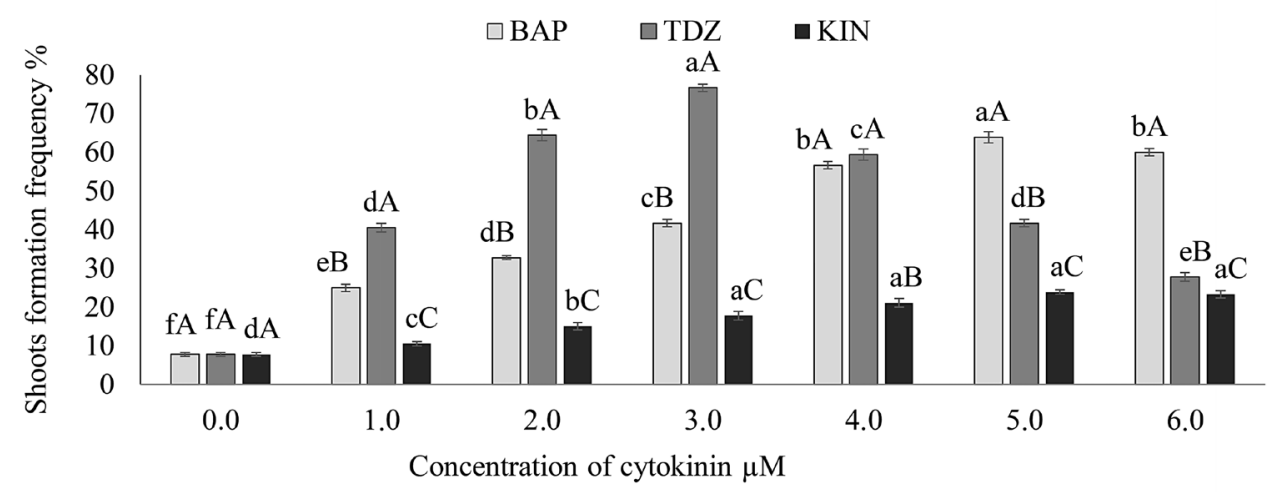

Note. Means + SE not sharing a common letter (in lower case letters - concentration of cytokinin, in capital letters - cytokinin types) are significantly different $(p<0.01)$.

Figure 2. Effect of cytokinin type and concentration on Stevia rebaudiana shoot formation frequency from stem explants 


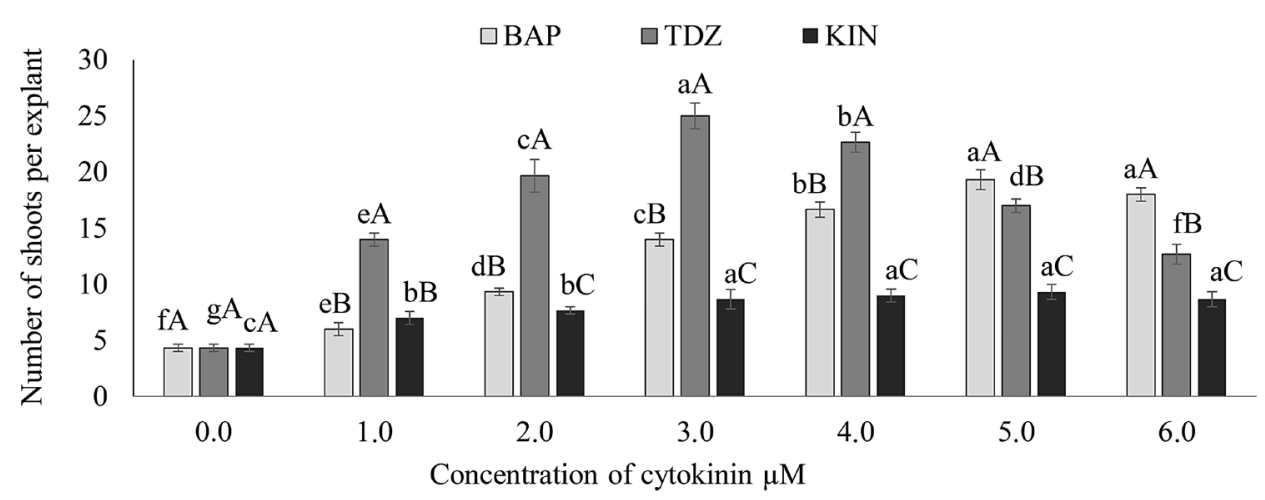

Explanation under Figure 2

Figure 3. Effect of cytokinin type and concentration on Stevia rebaudiana shoot number per explant from stem explants

Shoot formation frequency from leaf explants is presented in Figure 4. On the medium supplemented with BAP and KIN, the shoot regeneration frequency from leaf explant was significantly lower as compared to TDZ. On media supplemented with BAP, shoot formation frequency varied from $10.00 \%$ to $31.67 \%$ with an average of $23.15 \%$, and with KIN -- from $8.89 \%$ to
$20.56 \%$ with an average of $15.55 \%$. The shoot formation frequency from leaf explants increased with increasing BAP and TDZ concentration to $4.0 \mu \mathrm{M}$; however, higher concentration of these cytokinins significantly decreased shoot regeneration. The highest shoot formation frequency $(56.67 \%)$ from leaf explants was obtained on the medium supplemented with $4.0 \mu \mathrm{M}$ TDZ.

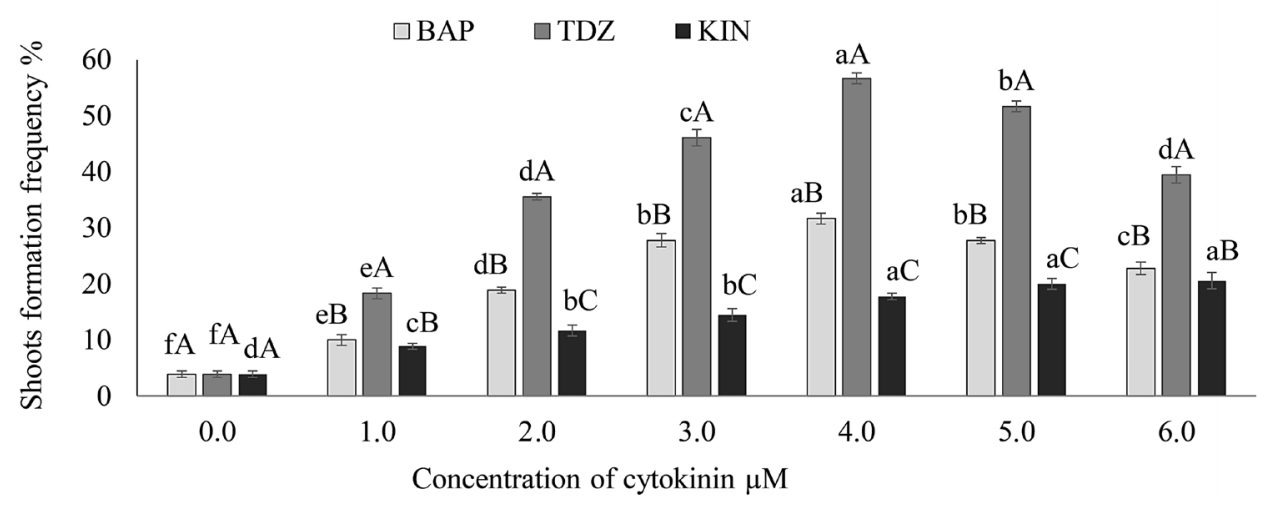

Explanation under Figure 2

Figure 4. Effect of cytokinin type and concentration on Stevia rebaudiana shoot formation frequency from leaf explants

When leaf explants were placed on the medium without growth regulators, shoot number per explant averaged 2.00. On the media supplemented with BAP, the shoot number per explant increased with increasing concentration to $5.0 \mu \mathrm{M}$. The highest number of shoots per explant $(32.67 \pm 0.88)$ was obtained on the medium supplemented with $4.0 \mu \mathrm{M}$ TDZ (Fig. 5).

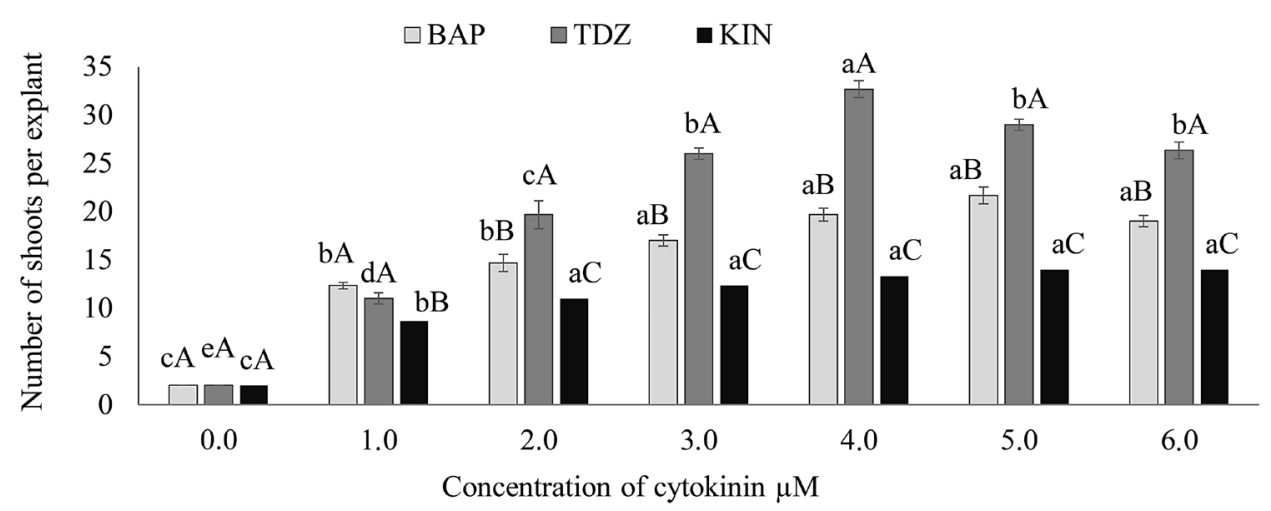

Explanation under Figure 2

Figure 5. Effect of cytokinin type and concentration on Stevia rebaudiana shoot number per explant from leaf explants 
External environmental factors are known to affect the overall plant growth and the accumulation of secondary metabolites. These factors include light, temperature and water availability (Akula, Ravishankar, 2011; Matos et al., 2014). In addition, some reports have documented that in $S$. rebaudiana the content of steviol glycosides has been affected by the propagation method (Nepovim et al., 1998). In vitro cultured plants of $S$. rebaudiana have been reported as having very similar growth pattern and contents of steviol glycosides to those of plants propagated through seeds, cuttings and stem tip (Bondarev et al., 2001). In this regard, considering the results of the current study, it was observed that on MS media supplemented with TDZ shoot formation frequency was significantly higher from stem segments and leaf explants in comparison with BAP and KIN. In a report by Lata et al. (2013) they also noted that TDZ was more effective for shoot formation of $S$. rebaudiana than BAP and KIN. In contrast, Röck-Okuyucu et al. (2016) reported that BAP was more effective than KIN and TDZ for the shoot multiplication. Our results are in agreement with Andlib et al. (2011), who documented that BAP stimulated the production of more shoots per explant compared with a similar concentration of KIN. Mehta et al. (2012) reported that MS media supplemented with $5.0 \mathrm{mg} \mathrm{L}^{-1}$ BAP were most suitable for shoot formation from nodal explants, while the highest number of shoots from apical and axillary nodes was observed in the medium supplemented with $2.0 \mathrm{mg} \mathrm{L}^{-1}$ BAP.

The analysis of variance revealed that explant type, cytokinin type, cytokinin concentration and their interaction significantly influenced shoot formation frequency as well as shoot number per explant (Table).

Table. Effect of different factors on Stevia rebaudiana shoot formation frequency and shoot number per explant

\begin{tabular}{|c|c|c|c|c|}
\hline Effect & $\begin{array}{c}F \text {-values of shoot } \\
\text { formation frequency } \\
\%\end{array}$ & $\begin{array}{l}p \text {-values for shoot } \\
\text { formation frequency } \\
\qquad \%\end{array}$ & $\begin{array}{c}F \text {-values of shoot } \\
\text { number } \\
\text { per explant }\end{array}$ & $\begin{array}{c}p \text {-values for shoot } \\
\text { number } \\
\text { per explant }\end{array}$ \\
\hline Explant type (A) & $1080.17 * *$ & $<0.000001$ & $261.49 * *$ & $<0.000001$ \\
\hline Cytokinin type (B) & $1680.24 * *$ & $<0.000001$ & $684.49 * *$ & $<0.000001$ \\
\hline Concentration of cytokinin (C) & $922.65 * *$ & $<0.000001$ & $429.03 * *$ & $<0.000001$ \\
\hline $\mathrm{A} \times \mathrm{B}$ & $182.86^{* *}$ & $<0.000001$ & $7.28 * *$ & $<0.000001$ \\
\hline $\mathrm{A} \times \mathrm{C}$ & $13.77 * *$ & $<0.000001$ & $33.96 * *$ & 0.001225 \\
\hline $\mathrm{B} \times \mathrm{C}$ & $113.36^{* *}$ & $<0.000001$ & $44.83 * *$ & $<0.000001$ \\
\hline $\mathrm{A} \times \mathrm{B} \times \mathrm{C}$ & $69.22 * *$ & $<0.000001$ & $19.25 * *$ & $<0.000001$ \\
\hline
\end{tabular}

** - significant at $P<0.01$

A significant effect $(p<0.01)$ of explant type on shoot regeneration frequency was observed. The mean value of regeneration frequency from stem segments was significantly higher in comparison with leaf segments (Fig. 6A). In addition, cytokinin type had a very significant effect on the shoot regeneration frequency. TDZ produced the highest mean regeneration frequency, significantly different from the other tested cytokinins (Fig. 6B). In terms of cytokinin concentration, the highest mean shoot formation frequency was obtained on the medium supplemented with $4.0 \mu \mathrm{M}$ of cytokinin (Fig. 6C)

Rafiq et al. (2007) obtained the maximum shoot multiplication from nodular stem segments of S. rebaudiana on the medium supplemented with $2.0 \mathrm{mg} \mathrm{L}^{-1}$ BAP. While Sridhar and Aswath (2014) reported that MS media supplemented with $2.0 \mathrm{mg} \mathrm{L}^{-1} \mathrm{BAP}$ $+0.5 \mathrm{mg} \mathrm{L}^{-1} \mathrm{KIN}+0.1 \mathrm{mg} \mathrm{L}^{-1} \mathrm{NAA}$ ( $\alpha$-naphthylacetic

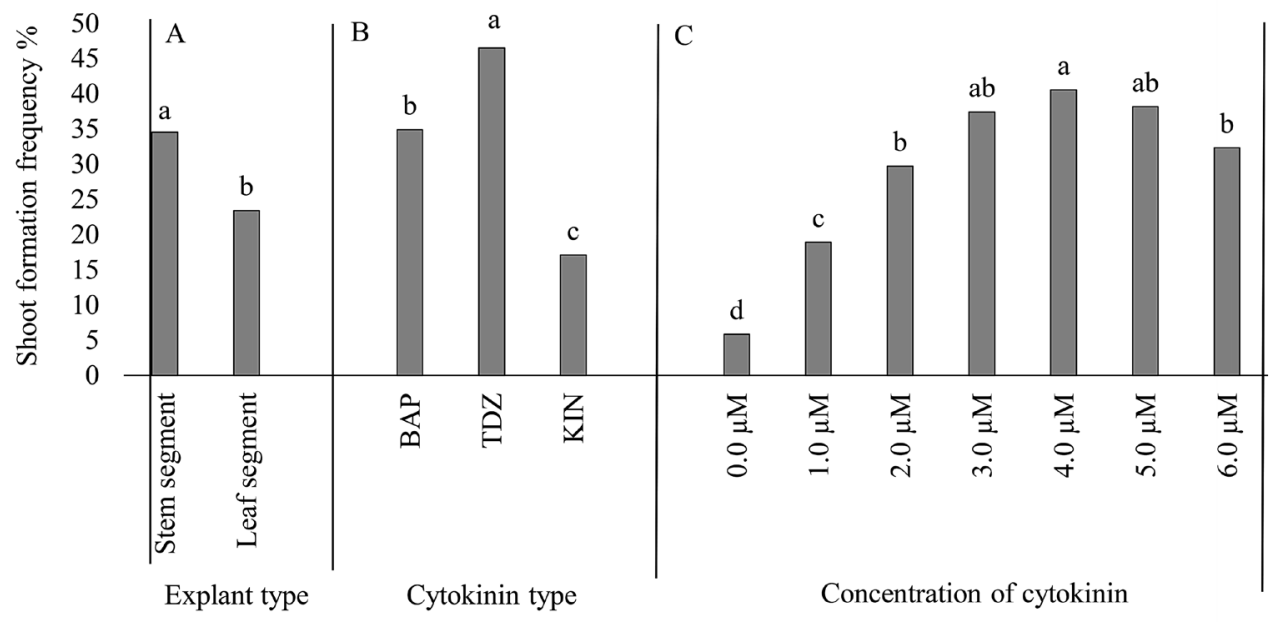

Note. Means not sharing a common letter are significantly different $(p<0.01)$.

Figure 6. Effect of explant type (A), cytokinin type (B) and cytokinin concentration (C) on the mean shoot regeneration of Stevia rebaudiana 
acid) were more appropriate for shoot formation from stem segments. In the present study, the highest shoot formation frequency was obtained from the stem segments, cultivated on the medium supplemented with 4.0 $\mu \mathrm{M}$ TDZ.

The analysis of the steviol glycosides by the HPLS showed that donor plants of S. rebaudiana contained $27.0 \mathrm{mg} \mathrm{g}^{-1}$ stevioside and $3.25 \mathrm{mg} \mathrm{g}^{-1}$ rebaudioside $\mathrm{A}$. The content of stevioside and rebaudioside $\mathrm{A}$ in the shoots, regenerated on the medium without growth regulators, was respectively 8.3 and 6.0 lower in comparison with the donor plants. Several times lower total content of the steviol glycosides in the in vitro grown $S$. rebaudiana plants, as compared to that in the greenhouse plants, was also obtained in Bondarev et al. (2001) and Ladygin et al. (2008) studies. Ladygin with co-authors (2008) suggest that low content of the steviol glycosides in in vitro grown $S$. rebaudiana plants is in accordance with poorly developed membrane system of chloroplasts.

Rebaudioside $\mathrm{A}$ is the most stable glycoside, it has no bitter aftertaste, in contrast to stevioside, and has higher economic value than stevioside (Marcinek, Krejpcio, 2015). Therefore, the ratio of rebaudioside A and stevioside was evaluated in this study.

Despite the changed content of stevioside and rebaudioside $\mathrm{A}$ in regenerated shoots, rebaudioside $\mathrm{A}$ and stevioside ratio was not changed in comparison with donor plants and was 0.12 (Fig. 7). Incorporation of BAP and TDZ into the nutrient medium resulted in a decrease in stevioside content and an increase in rebaudioside A content in the regenerated shoots; therefore, under the influence of these cytokinins, a significant increase in rebaudioside $\mathrm{A}$ and stevioside ratio was obtained. Conversely, incorporation of KIN into the culture medium resulted in a decrease in stevioside and rebaudioside $\mathrm{A}$ contents in the regenerated shoots; therefore, under the influence of this cytokinin, a decrease in rebaudioside A and stevioside ratio was obtained.

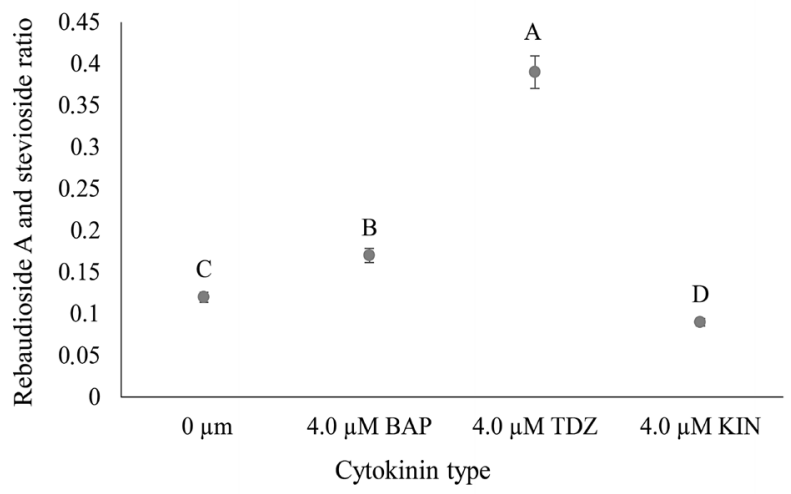

Note. Means + SE not sharing a common letter are significantly different $(p<0.01)$.

Figure 7. Effect of cytokinin type on the ratio of steviol glycosides

Gupta et al. (2015) reported that $\mathrm{NaCl}$, $\mathrm{Na}_{2} \mathrm{CO}_{3}$, proline and polyethylene glycol could enhance the production of steviol glycoside in $S$. rebaudiana regenerants cultured in vitro. In the present study, the highest rebaudioside $\mathrm{A}$ and stevioside ratio was determined in the shoots cultured on the medium supplemented with $4.0 \mu \mathrm{M}$ TDZ.

The obtained results can be useful for further experiments for the selection of appropriate TDZ concentration for production of $S$. rebaudiana plants with a valuable rebaudioside $\mathrm{A}$ and stevioside ratio.

\section{Conclusions}

1. The average shoot formation frequency from Stevia rebaudiana stem segments was significantly higher than from leaf segments; therefore, stem segments are more suitable for shoot formation in vitro.

2. On the medium supplemented with thidiazuron (TDZ), $S$. rebaudiana shoot formation frequency from the tested explants was significantly higher than on the media supplemented with 6-benzylaminopurine (BAP) and kinetin (KIN).

3. The highest $S$. rebaudiana shoot formation frequency was obtained from stem segments, cultured on the medium supplemented with $3.0 \mu \mathrm{M}$ TDZ.

4. Rebaudioside $\mathrm{A}$ and stevioside ratio in the medium supplemented with $4.0 \mu \mathrm{M}$ TDZ was significantly higher than that in the media supplemented with $4.0 \mu \mathrm{M}$ BAP and $4.0 \mu \mathrm{M}$ KIN.

Received 22072019

Accepted 21012020

\section{References}

1. Akula R., Ravishankar G. A. 2011. Influence of abiotic stress signals on secondary metabolites in plants. Plant Signaling and Behavior, 6: 1720-1731.

https://doi.org/10.4161/psb.6.11.17613

2. Andlib A., Verma R. N., Batra A. 2011. Synthetic seeds an alternative source for quick regeneration of a zero calorie herb-Stevia rebaudiana Bertoni. Journal of Prharmacy Research, 4: 2007-2009.

3. Anton S. D., Martin C. K., Han H., Coulon S., Cefalu W. T., Geiselman P., Williamson D. A. 2010. Effects of stevia, aspartame, and sucrose on food intake, satiety, and postprandial glucose and insulin levels. Appetite, 55 (1): $37-43$.

https://doi.org/10.1016/j.appet.2010.03.009

4. Bergs D., Burghoff B., Joehnck M., Martin G., Schembecker G. 2012. Fast and isocratic HPLC-method for steviol glycosides analysis from Stevia rebaudiana leaves. Journal of Consumer Protection and Food Safety, 7: $147-154$. https://doi.org/10.1007/s00003-012-0760-5

5. Bondarev N., Reshetnyak O., Nosov A. 2001. Peculiarities of diterpenoid steviol glycoside production in in vitro cultures of Stevia rebaudiana Bertoni. Plant Science, 161 (1): 155-163.

https://doi.org/10.1016/S0168-9452(01)00400-9

6. Chan P., Tomlinson B., Chen Y. J., Liu J. C., Hsieh M. H., Cheng J. T. 2000. A double-blind placebo-controlled study of the effectiveness and tolerability of oral stevioside in human hypertension. British Journal of Clinical Pharmacology, 50: 215-220. https://doi.org/10.1046/j.1365-2125.2000.00260.x

7. Chaturvedula V. S. P., Prakash I. 2011. Acid and alkaline hydrolysis studies of stevioside and rebaudioside A. Journal of Applied Pharmaceutical Science, 1: 104-108. 
8. Compton M. E. 1994. Statistical methods suitable for the analysis of plant tissue culture data. Plant Cell, Tissue and Organ Culture, 37: 217-242.

9. Dey A., Kundu S., Bandyopadhyay A., Bhattacharjee A. 2013. Efficient micropropagation and chlorocholine chloride induced stevioside production of Stevia rebaudiana Bertoni. Comptes Rendus Biologies, 336: 17-28. https://doi.org/10.1016/j.crvi.2012.11.007

10. George E. F., Debergh P. C. 2008. Micropropagation: uses and methods. George E. F. et al. (eds). Plant propagation by tissue culture. Springer, p. 29-64. https://doi.org/10.1007/978-1-4020-5005-3 2

11. Gupta P., Sharma S., Saxena S. 2015. Biomass yield and steviol glycoside production in callus and suspension culture of Stevia rebaudiana treated with proline and polyethylene glycol. Applied Biochemistry and Biotechnology, 176: 863-874. https://doi.org/10.1007/s12010-015-1616-0

12. Jain P., Kachhwaha S., Kothari S. L. 2009. Improved micropropagation protocol and enhancement in biomass and chlorophyll content in Stevia rebaudiana (Bert.) Bertoni by using high copper levels in the culture medium. Scientia Horticulturae, 119 (3): 315-319. https://doi.org/10.1016/j.scienta.2008.08.015

13. Ladygin V. G., Bondarev N. I., Semeniva G. A., Smolov A. A., Reshetniak O. V., Nosov A. M. 2008. Chloroplast ultrastructure, photosynthetic apparatus activities and production of steviol glycosides in Stevia rebaudiana in vivo and in vitro. Biologia Plantarum, 52: 9-16. https://doi.org/10.1007/s10535-008-0002-y

14. Lata H., Chandra S., Wang Y. H., Raman V., Khan I. A. 2013. TDZ-induced high frequency plant regeneration through direct shoot organogenesis in Stevia rebaudiana Bertoni: an important medicinal plant and a natural sweetener. American Journal of Plant Sciences, 4: 117-128. https://doi.org/10.4236/ajps.2013.41016

15. Lee C. N., Wong K. L., Liu J. C., Chen Y. J., Cheng J. T., Chan P. 2001. Inhibitory effect of stevioside on calcium influx to produce antihypertension. Planta Medica, 67: 796-799. https://doi.org/10.1055/s-2001-18841

16. Lemus-Mondaca R., Vega-Gálvez A., Zura-Bravo L., Ah-Hen K. 2012. Stevia rebaudiana Bertoni, source of a high-potency natural sweetener: a comprehensive review on the biochemical, nutritional and functional aspects. Food Chemistry, 132: 1121-1132.

https://doi.org/10.1016/j.foodchem.2011.11.140

17. Lopes S. M., Krausová G., Rada V., Gonçalves J. E., Gonçalves R. A. C., de Oliveira A. J. B. 2015. Isolation and characterization of inulin with a high degree of polymerization from roots of Stevia rebaudiana (Bert.) Bertoni. Carbohydrate Research, 411: 15-21. https://doi.org/10.1016/j.carres.2015.03.018

18. Luwańska A., Perz A., Mańkowska G., Wielgus K. 2015. Application of in vitro stevia (Stevia rebaudiana Bertoni) cultures in obtaining steviol glycoside rich material. Herba Polonica, 61: 50-63.

https://doi.org/10.1515/hepo-2015-0010

19. Madan S., Ahmad S., Singh G. N., Kohli K., Kumar Y., Singh R., Garg M. 2010. Stevia rebaudiana (Bert.) Bertoni - a review. Indian Jounal of Natural Products and Resources, 1: 267-286.

20. Marcinek K., Krejpcio Z. 2015. Stevia rebaudiana Bertoni chemical composition and functional properties. Acta Scientiarum Polonorum Technologia Alimentaria, 14: $145-152$.

21. Matos D. A., Cole B. J., Whitney I. P., MacKinnon K. J. M., Kay S. A., Hazen S. P. 2014. Daily changes in temperature, not the circadian clock, regulate growth rate in Brachypodium distachyon. PLoS ONE, 9 (6): e100072. https://doi.org/10.1371/journal.pone.0100072
22. Mehta J., Khan S., Bisht V., Syedy M., Rathore R., Bagari L. 2012. High frequency multiple shoots regeneration and callus induction an anti diabetic plant - Stevia rebaudiana Bertoni - an important medicinal plant. American Journal of Pharmtech Research, 2: 19-27.

23. Moharami L., Hosseini B., Ravandi E. G., Jafari M. 2014. Effects of plant growth regulators and explant types on in vitro direct plant regeneration of Agastache foeniculum, an important medicinal plant. In Vitro Cellular and Developmental Biology - Plant, 50: 707-711.

https://doi.org/10.1007/s11627-014-9640-2

24. Murashige T., Skoog F. 1962. A revised medium for rapid growth and bioassays with tobacco tissue cultures. Physiologia Plantarum, 15: 473-497. https://doi.org/10.1111/j.1399-3054.1962.tb08052.x

25. Nepovim A., Drahosova H., Valicek P., Vanek T. 1998. The effect of cultivation conditions on the content of stevioside in Stevia rebaudiana Bertoni plants cultivated in the Czech Republic. Pharmaceutical and Pharmacological Letters, 8: 19-21. https://doi.org/10.1002/jsfa.6016

26. Rafiq M., Dahot M. U., Mangrio S. M., Naqvi H. A., Qarshi I. A. 2007. In vitro clonal propagation and biochemical analysis of field established Stevia rebaudiana Bertoni. Pakistan Journal of Botany, 39: 2467-2474.

27. Raudonius S. 2017. Application of statistics in plant and crop research: important issues. Zemdirbyste-Agriculture, 104 (4): 377-382. https://doi.org/10.13080/z-a.2017.104.048

28. Razak U. N. A. A., Ong C. B., Yu T. S., Lau L. K. 2014. In vitro micropropagation of Stevia rebaudiana Bertoni in Malaysia. Brazilian Archives of Biology and Technology, 57: 23-28.

https://doi.org/10.1590/S1516-89132014000100004

29. Röck-Okuyucu B., Bayraktar M., Akgun I. H., Gurel A. 2016. Plant growth regulator effects on in vitro propagation and stevioside production in Stevia rebaudiana Bertoni. HortScience, 51: 1573-1580. https://doi.org/10.21273/HORTSCI11093-16

30. Singh P., Dwivedi P. 2013. Efficient micropropagation protocols of regeneration of Stevia rebaudiana Bertoni, an anti-diabetic herb. Vegetos, 26: 318-323. https://doi.org/10.5958/j.2229-4473.26.1.046

31. Sivaram L., Mukundan U. 2003. In vitro culture studies on Stevia rebaudiana. In vitro cellular and developmental biology. Plant, 39 (5): 520-523. https://doi.org/10.1079/IVP2003438

32. Sridhar T. M., Aswath C. R. 2014. Influence of additives on enhanced in vitro shoot multiplication of Stevia rebaudiana (Bert.) - an important anti diabetic medicinal plant. American Journal of Plant Sciences, 5: 192-199. https://doi.org/10.4236/ajps.2014.51025

33. Thiyagarajan M., Venkatachalam P. 2012. Large scale in vitro propagation of Stevia rebaudiana (Bert.) for commercial application: pharmaceutically important and antidiabetic medicinal herb. Industrial Crops and Products, 37: 111-117. https://doi.org/10.1016/j.indcrop.2011.10.037

34. U.S. Food and Drug Adminstration. 2018. Has stevia been approved by FDA to be used as a sweetener? https://www. fda.gov/about-fda/fda-basics/has-stevia-been-approvedfda-be-used-sweetener

35. Yadav A. K., Singh S., Dhyani D., Ahuja P. S. 2011. A review on the improvement of stevia (Stevia rebaudiana Bertoni). Canadian Journal of Plant Science, 91: 1-27. https://doi.org/10.4141/cjps10086 
ISSN 1392-3196 / e-ISSN 2335-8947

Zemdirbyste-Agriculture, vol. 107, No. 2 (2020), p. 171-178

DOI $10.13080 /$ z-a.2020.107.022

\title{
Stevia rebaudiana organogenezę ir steviolio glikozidu kaupimąsi in vitro lemiantys veiksniai
}

\author{
A. Blinstrubienè, N. Burbulis, N. Juškevičiūtè, R. Žūkienė \\ Vytauto Didžiojo universitetas
}

\section{Santrauka}

Tirta eksplanto ir citokininų tipų bei koncentracijos įtaka saldžiosios stevijos (Stevia rebaudiana Bertoni) tiesioginei organogenezei ir citokininų tipo poveikis steviozido bei rebaudiozido A kaupimuisi in vitro. Ūglių indukcijai stevijos stiebo ir lapo segmentai, izoliuoti iš 6 savaičių amžiaus in vitro augalų, auginti Murashige ir Skoog (MS) maitinamojoje terpeje, papildytoje skirtingomis $(1,0-6,0 \mu \mathrm{M})$ 6-benzilaminopurino (BAP), tidiazurono (TDZ) ir kinetino (KIN) koncentracijomis. Steviolio glikozidų (steviozido ir rebaudiozido A) kiekis donoriniuose augaluose ir susiformavusiuose ūgliuose įvertintas taikant aukšto slègio skysčiu chromatografiją. Dispersinès analizès rezultatai parodė, kad ūglių formavimosi dažniui esminès įtakos $(p<0,01)$ turèjo visi tirti veiksniai. Nustatyta, kad stiebo segmentai ūglius formavo esmingai didesniu dažniu nei lapo segmentai. Maitinamojoje terpejje, papildytoje tidiazuronu, izoliuoti eksplantai ūglius formavo intensyviau nei maitinamojoje terpèje, papildytoje 6-benzilaminopurinu arba kinetinu. Didžiausias vidutinis ūglių formavimosi dažnis gautas maitinamojoje terpeje, papildytoje 3,0 $\mu \mathrm{M}$ TDZ. Stevijos tiesioginę organogenezę indukavus maitinamojoje terpeje, papildytoje $4 \mu \mathrm{M}$ BAP arba 4,0 $\mu \mathrm{M}$ TDZ, rebaudiozido A ir steviozido santykis ūgliuose didejjo, o terpeje su 4,0 $\mu \mathrm{M}$ KIN priedu mažèjo. Esmingai didesnis rebaudiozido A ir steviozido santykis nustatytas maitinamojoje terpeje, papildytoje 4,0 $\mu \mathrm{M}$ TDZ, nei terpèse, papildytose 4,0 $\mu \mathrm{M}$ BAP arba 4,0 $\mu \mathrm{M}$ KIN.

Reikšminiai žodžiai: citokininai, eksplantas, rebaudiozidas A, saldžioji stevija, steviozidas, ūglių regeneracija. 